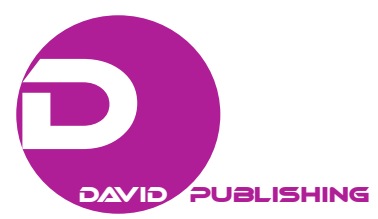

\title{
Turkey, Iran, Russia, and China Building a New Oil Bourse: Strategic Steps or Political Blackmail
}

\author{
Basma Khaleel Namuq, Mohamed Aziz Abdel-Hassan \\ University of Baghdad, Baghdad, Iraq
}

\begin{abstract}
Through our research, we tried to ask the following substantive questions: Is the creation of an oil exchange that depends mainly on the euro in its commercial dealings, and a regional and international financial system for trade in local currencies between Turkey, Iran, Russia, China, and the European Union, which could contribute to stopping the continued deterioration of the Turkish lira and the Iranian riyal? Will the use of local currencies in trade be able to achieve positive benefits supporting both the Iranian economy and Turkey or the use of local currencies in the trade of these countries (Turkey and Iran) will be of benefit only to China, Russia, Iran, Ukraine, and other countries that have Iran and Turkey trade the largest with these countries alone? Will the reserves of some countries shift from the dollar to the euro, such as China, Russia, and other countries, and will this turn into a pressure card for political gains and the threat of using the euro as a difficult currency? Has the United States become blackmailed in this area? Therefore, the United States will not allow the European Union, China, Iran, or Turkey to establish a regional or international financial system to replace the sale of oil in euros instead of the dollar because in the new international balance, the United States will not fear Russia, China, or the European Union, which have close economic, technical, and political relations and interests with America. For the United States, these countries are not adversaries, but competitive trading partners. What brings them closer to the United States?
\end{abstract}

Keywords: Turkey, Iran, Russia, China, international banking system, local currencies

\section{Introduction}

\section{The Question Arises From the Following Thematic Questions}

First, is the establishment of an oil exchange that depends mainly on the euro in its commercial dealings, and a regional and international financial system for local currency exchange between Turkey, Iran, Russia, China, and the European Union, which could contribute to stopping the continued deterioration of the Turkish lira and the Iranian riyal?

Second, is the use of local currencies in trade exchange possible to achieve positive benefits that support both the Iranian and Turkish economies or the use of local currencies in the trade of these countries (Turkey and Iran) will be of benefit only to China, Russia, Iran, Ukraine, and other countries that have Iran and Turkey greater trade exchange with these countries alone?

Are the European countries, Russia, and China ready to share the idea of Turkey and Iran that establishing a system of banking system to use the local currency in its commercial transactions?

Basma Khaleel Namuq, M.A., assistant professor, College of Political Science, University of Baghdad, Baghdad, Iraq.

Mohamed Aziz Abdel-Hassan, Ph.D., assistant professor, College of Political Science, University of Baghdad, Baghdad, Iraq. 
Are European countries, China, and Russia serious about stepping down from the US dollar and dealing with the euro and local currencies in their trade dealings with Turkey and Iran?

Third, if real and not virtual, will the establishment of a regional and international banking system between Turkey and Iran with the European Union, Russia, and China to deal with local currencies in trade exchange, petro-euro replace petro-dollar?

Will the reserves of some countries shift from the dollar to the euro, such as China, Russia, and other countries, and will this turn into a pressure card for political gains and the threat of using the euro as a difficult currency?

Has the United States become blackmailed in this area?

But the question remains, to what extent can Middle Eastern countries adopt the euro as the basis for trade in the oil trade instead of the dollar to talk about petro-euro instead of petro-dollar?

The hypotheses of the research start from the following:

First, despite the US $\$ 800$ billion budget deficit, this does not mean that it has become extinct. It continues to drive the world economy, the world's largest consumer market, and the world's leading export.

Second, foreigners are still rushing to buy American commercial assets and that the transfer of the dollar from America to China, India, and the Middle East is the cornerstone for the launch of investors in these countries.

Third, it is impossible to change the language of the oil discourse, which is based mainly on dollar, not euro or any other international currency.

Since oil is by far the most important commodity for world trade as the engine of modern industry, the refusal of the Organization of the Petroleum produces countries to sell its oil in euro instead of dollar.

As long as this continues, the euro is not expected to become the main reserve currency for following reasons (Maraashli, 1987).

First, Europeans do not want to put pressure on the US dollar because of the impact on their interests and strategic partnership with America and other reasons related to oil prices and the strength of the euro.

Second, a sharp drop in the US dollar will bring catastrophic consequences to many countries. With the increasing US desire for oil and the importation of goods at cheap prices from India and China, it is not in the interest of the global economy to enter into economic conflict with America, because the occurrence of such a thing will require the Europeans and Asians to sustain the wheel of the American economy and consumer capacity of Americans.

Third, the only country that requested the euro instead of the dollar as payments for oil was Iraq in 2000. His request was initially met with ridicule and then ignored. The war in Iraq in 2003 to defend the dollar was a lesson for others who might follow the same path as Iraq (Mahmoud, 2003).

The demand for non-dollar payments by any country will be the same and will be punished.

Two months after the invasion of Iraq, the oil-for-food program was canceled, and all the Iraqi accounts that were designed to deal with the euro turned into dollars. No country in the world is buying Iraqi oil in euros, and the dollar's dominance over oil sales payments has re-established.

US President George W. Bush announced that the mission was accomplished and declared himself victorious. He succeeded in defending the dollar and the American empire (Momen, 2012).

Fourth, the Americans lead the global oil trade from the US-owned New York and London stock exchanges. 
Even the London Stock Exchange has been adopting the dollar instead of the euro so far.

Therefore, the United States will not allow the European Union, China, Iran, or Turkey to establish a regional or international financial system to replace the sale of oil in euros instead of the dollar.

Because in the new international balance, the United States will not fear Russia, China, or the European Union, which have close economic, technical, and political relations and interests with America. For the United States, these countries are not adversaries, but competitive trading partners. What brings them closer to the United States?

When asked Mrs. Albright "What exactly is it worth killing half a million Iraqi children?", the response was that in November 2000, Iraq began selling oil exclusively to the euro. This is a direct attack on the dollar and the economic hegemony of the United States, which America could not condone (Timerman, 2006).

\section{What Are the Main Benefits Gained From the Establishment of a Regional or International Bank for Local Currencies and Their Use in Foreign Trade Between Turkey, Iran, Russia, China, and Other Countries}

The deterioration of US-Turkish relations after the US Revolt and the cancellation of US President Trump's nuclear agreement with Iran have seriously affected both the Iranian and Turkish economies, so that the following facts were revealed:

First, reflecting the deterioration of the US-Turkish relations and the consequences of the cancellation of the nuclear agreement with Iran by the US on the value of the local currencies (Turkish and Iranian) against the US dollar and increasing further.

Both the Turkish lira and the Iranian riyal are one of the local currencies in developing countries, and have been most affected by the appreciation of the US dollar.

Second, the devaluation of the Turkish lira, the Iranian riyal, and other local currencies in developing countries also negatively affect the cost of foreign trade (Howard, 2007).

For this reason, he reintroduced the proposal to use the local currency in trade instead of the US dollar, which has the largest share in world trade.

Local currency trade is defined as the trade in which each country's local currency is used in inter-country trade without resorting to a common currency, such as the US dollar. The system, also known as currency exchange, plays an important role in the effectiveness of central banks and the appropriateness of financial institutions to each other. The exchange of local currencies needed by the two countries to conduct mutual trade will be carried out by financial institutions headed by the central bank (Hassan, 2006).

The benefits of foreign trade in local currency, in terms of preventing the negative effects of changes in the foreign exchange rate on foreign trade, can be included as follows:

(1) Lower operational cost of foreign trade, to the lowest.

(2) Lift losses caused by trade and the dollar.

(3) Increasing emphasis on foreign trade for the private sector (Al-Atrisi, 2006).

(4) Strengthening trade cooperation among developing countries.

(5) Strengthening the position of the local currency against the movement of speculation and reduce the risks.

(6) Reducing the sensitivity of the reserve and topped the US dollar against the local currency ${ }^{1}$.

\footnotetext{
${ }^{1}$ Decisions of Iran's economic war room: By linking Iran’s currency to. Retrieved from https://iiardpub.org/get/JPSLR/VOL.../ Decisions\%20of\%20Iran's\%20economic.pdf.
} 


\section{What Are the Implications of Building a New Oil Exchange}

What are the reactions of the United States of America to the construction of a new oil exchange selling oil in euros instead of the dollar?

There are historical precedents to try to find alternatives to dollar in international transactions. For example, after the global financial crisis in 2008, China took the base to abandon the use of the dollar as the international currency in the settlement of international transactions, a paper to pressure America, called under the BRIX Group (Brazil, Russia, China, India, and South Africa) to make trade adjustments in terms of local currency, dealing with the dollar, due to economic and financial problems, as well as China with the ASEAN (Association of Southeast Asian Nations) countries and other neighboring countries and the regional environment ${ }^{2}$.

In the same vein, Turkey announced the same approach, settling foreign transactions with neighboring countries within local currencies, but both the Turkey and China experiments have not yet announced their results. Even local currency adjustments have only entries in the currency, local, neither in the experience of the BRIX, nor in the Turkish experience.

The World Bank provided accurate statistics for BRIX, particularly its GDP and GDP for 2012 compared to 2014.

The results were as follows:

World Bank statistics: BRIX GDP exceeds $\$ 16$ trillion by the end of 2014, and China alone is increasing its gross domestic product from $\$ 10$ trillion, while Iran’s GDP is $\$ 425.2$ billion. GDP is low ${ }^{3}$.

There are a number of problems in the relations of some members of the BRIX Group with the United States in particular, which makes it take this position, although it resorted to in a purely political context, but the United States considers it seeks from those countries to remove the dollar as the main currency of international settlements and the formation of international reserves in central banks. Thus, after the imposition of economic sanctions by the United States and Europe, Russia tends to accept the settlement of transactions in local currencies with some countries as a kind of economic war, especially for the US dollar ${ }^{4}$.

The Turkish lira lost more than $40 \%$ of its value and threatened to lose purchasing power in the coming months.

What are the strategic alternatives, not the default alternatives, which can save both the Iranian and Turkish economies from the repercussions of the US economic and financial sanctions imposed on them?

Is it possible that the threat of Turkish President Erdogan to abandon dealing with the dollar in Turkish business transactions may lead to positive results to protect the Turkish lira and the Iranian riyal from the continuous decline in value and purchasing power?

Are they subject to the response of the countries concerned, particularly Russia, China, and other countries with which we have the largest trade?

Will we see the nucleus of establishing a regional and international bank for local currencies in foreign trade exchanges instead of the dollar soon or is it just a way to extort the United States?

First, the volume of trade between Turkey, Iran, Russia, and China could achieve this and make it a reality

\footnotetext{
${ }^{2}$ Bracing for US sanctions, Iran lifts ban on. The Times of Israel. Retrieved from https://www.timesofisrael.com/bracing-for -us-sanctions-Iran-lifts-ban-on-exchange-of.

${ }^{3}$ Will Iran, China, Russia push US dollar to the brink of extinction. Retrieved from https://sputniknews.com/.../2015122810324 22450-iran-china-russia-dedollarization-e.

${ }^{4}$ Iran in a changing strategic environment. Center for Security Studies. Retrieved from http://www.css.ethz.ch/.../INSS_Iran\%20 Changing\%20Strategic\%20Environment.pdf.
} 
rather than a dream by default. According to the Turkish Statistical Institute, which reached 26.31 billion dollars in 2017, China ranked first in terms of imports, which reached 23.37 billion dollars in 2017, accounting for 10\% of Turkey's total imports, down 8.1\% for the year 2016 (Al-Rawai, 2003).

Second, the establishment of a local currency bank in external trade between countries affected by US sanctions may precede practical steps in the field of import and export. May begin with agricultural products and then develop into other industrial and military fields (Mohammed, 2007).

The most prominent proof of this is that: Russian Deputy Prime Minister Arkady Dvorkovic said his country would gradually begin importing tomatoes from Turkey without harming local production of the product and that Russia was no different from Turkey in agricultural trade.

He added that his government received a proposal from the Ministry of Agriculture, which includes the import of 50,000 tons of Turkish tomatoes annually, provided that this import outside the harvest season in Russia, where he said: "I think that concrete steps must be taken on tomatoes, limited without harming Russian producers For this product” (Duran, 2011, p. 26).

Deputy Prime Minister of Russia, to continue his country's talks with Turkish officials on a regular basis, considering that the status of the Turkish government requirement of approval of the consulate or commercial attaché in Russia, and the import of Russian products, is not a new problem for the two countries (Turkish and Russian).

Third, the use of national currencies instead of the dollar in foreign transactions between Iran, Russia, Turkey, China, and other countries needs time and study.

Russian Press Secretary Dmitry Piskov confirmed that Russia is seeking to use national currencies to settle trade accounts with Turkey, but there is a need for careful consideration (Hazem, 2003, p. 78).

The subject of the use of national currencies in mutual trade is the subject on which the Russian side has been going on for a long time, at various levels, including at the highest level, where President Putin has repeatedly talked about not such a possibility, and even more. Of course, all of this needs careful study and accurate calculations, but this is what we seek in bilateral trade and economic relations, a subject we have talked about repeatedly in the framework of the Russian-Turkish talks, the Sino-Russian talks, and the Iranian-Russian talks.

Fourth, trade in local currency became more important and showed the position of countries, particularly developing countries, on the establishment of the new financial system. In view of the G20 meeting in China, we believe that initiatives to conduct foreign trade using the local currency provided by Turkey have been assessed as a path to the search for a new economic and financial system ${ }^{5}$.

Recently, steps have been taken on the use of domestic currencies in foreign trade with Iran, Russia, and China in the form of supportive political measures.

Given the size of imports, which are important in Turkey’s foreign trade, China ranks first.

In recent years, China has also made an effort to convert its local currency, the Chinese Yen, into an international currency used worldwide. In addition, agreements between Turkey and China on currency exchange will be reflected in the trade relations that are still ongoing between the two countries, which will in turn enhance the prospects of a new alternative trade regime, which will be part of the Turkish lira ${ }^{6}$.

\footnotetext{
5 Turkey, China and Iran Look to a Future Without the Dollar. Is it? Retrieved from https://www.albawaba.com/.../turkey-chinaand-Iran-look-future-without-dollar-it-pos.

6 Turkey, China realize first currency swap transaction in a move to use. Retrieved from https://www.dailysabah.com/.../turkeychina-realize-first-currency-swap-transaction-in.
} 
Russia, the most important partner in foreign trade, is in terms of the cost of energy imports, which is the source of the main problem in the current account deficit.

Doing business in local currency with Russia will increase the negative impact that may result from foreign exchange. Reducing the cost of energy imports will positively affect the current account deficit. In this context, it will help clarify the relationship between the Turkish lira and ruble and its importance.

In addition, the new agreements to be signed with countries that will increase the volume of trade and energy cooperation with them, and on the basis of the local currency, will contribute to reducing unnecessary costs (Baylawi, 2001).

And that the acceleration of Russia, China, Iran, and Turkey to sign a four-currency agreement to establish a stock exchange in foreign trade will contribute significantly to reduce the cost of foreign exchange and contribute to the development of trade in the region.

Thus, the local currency trade led by Turkey, Iran, Russia, and China will have the domino effect worldwide, leading to the ability to accelerate the establishment of a new trade and economic system in the world.

The United States has global financial sovereignty, represented by the US dollar or global financial sovereignty, which is also the rule of the petrodollar. America has now become an undisputed superpower (Omar, 1998).

Is the United States prepared to use all military, economic, and financial means to deter Turkey, Iran, Russia, and China and prevent them from crossing its global financial sovereignty, the dollar of oil or not?

The answer would be: To the Iranian government.

That your decision to sell Iranian oil in euros instead of the dollar may contribute to accelerate the US attack on Iran and change its political system.

And that the efforts of Turkey, Russia, China, and Iran to use domestic currencies in foreign trade will not go unnoticed, but will impose the United States of America further economic and financial sanctions on these countries.

In 2003, the United States invaded Iraq, and once control of the country, the dollar returned to be the approved currency for the sale of Iraqi oil (Arafa, 2014) ${ }^{7}$.

Will we see the US invasion of Iran in late 2018?

Once Iran is controlled, the dollar will return as the official currency to sell Iranian oil instead of the euro!

In March 2007, the US Congressional Defense Office said “A memorandum describing how we will strike seven countries within five years, starting with Iraq, then Syria, Lebanon, Libya, Somalia, Sudan and Iran”.

In Libya, Gaddafi was organizing a unit of African countries to create one currency, the Golden dinar, which was supposed to be used to replace the dollar in that region.

More than a third of Iran's oil exports go to Europe, making the US administration seriously planning to deter Tehran.

Iran succeeds in selling its oil in euros instead of the dollar. If it succeeds, can Iran disrupt supply and demand in the oil market?

And how do energy and oil experts look at the future of Iranian work by replacing the sale of oil in euros instead of the dollar?

\footnotetext{
${ }^{7}$ Why is oil priced and traded in U.S. dollars? Retrieved from https://www.quora.com/topic/Euro-currency.
} 
All energy experts and stakeholders confirm the following facts ${ }^{8}$ :

The first is to reduce the impact of Iran's conversion to the euro in settling the accounts of the sale and purchase of oil on the dollar exchange rate. Second, at present, in 2018, there is no threat to the dollar as the single currency in oil contracts. Sixty to seventy percent of global imports and exports are in dollars, and the dollar accounts for about $60 \%$ of the world's hard currency reserves. Third, the US currency is the instrument of dealing in about $80 \%$ of global financial markets operations and $70 \%$.

The issue of loans is provided by banks around the world.

Oil, energy, and oil experts in London and New York wonder about Iran and its ability to replace the sale of oil in euros instead of the dollar or any currency other than the dollar in the oil trade. "If you trade in oil, you have to keep the dollar and I do not think anyone will use the euro, yen or other currency as the world oil market currency during the decade" ${ }^{\text {. }}$.

Energy and oil experts on the London Stock Exchange and New York question the question of Iran and its ability to replace the sale of its oil in euros instead of the dollar or any currency other than the dollar in the oil trade ${ }^{10}$.

"If you trade oil, you have to keep the dollar. I do not think anyone will use the euro, ruble, yen or other as the currency of the world oil market during the decade", said the former governor of the world oil market. Central Bank of Russia, current Chairman of Yukos Board of Directors, Viktor Gerashchenko ${ }^{11}$.

\section{Conclusions}

The signing of the Iranian monetary agreements with Turkey and Iraq will be a strong justification for the United States of America to impose economic and financial sanctions and will not be borne by their economies (Iraq and Turkey, the sources referred to the entry into force of the Convention Agreement between Turkey and Iran in the national currency and the riyal on July 4, 2018).

To facilitate trade with neighboring countries, and direct the monetary operations of natural and legal persons towards the banking system, we use international payment instruments, reduce the risks of monetary operations, and adopt a policy to conclude monetary agreements and currency exchange with major countries in terms of treatment.

He added that the Iranian bank "Melli" opened the first document of commercial financing between Iran and Turkey, under the exchange agreement between the two currencies and the lira between the two central banks in the two countries, according to the news agency "Knight". "The agreement does not require the use of a third currency, such as the United States”. Exchange of dollars in dollars, adding that according to this model, will be directed to the procurement and transfers and exchanges to the banking system.

The signing of the Iranian monetary agreements with Turkey and Iraq will be a strong justification for the United States of America to impose economic and financial sanctions and will not be borne by their economies (Iraq and Turkey, the sources pointed to the entry into force of the exchange agreement between Turkey and

\footnotetext{
${ }^{8}$ Is it true that the Iraq war happened because Iraq started selling. Retrieved from https://www.quora.com/Is-it-true-that-the-Iraq -war-happened-because-Iraq-started-SELLIN.

${ }^{9}$ Debunking the Dumping-the-Dollar Conspiracy, Foreign Policy. Retrieved from https://foreignpolicy.com/2009/10/07/debunk ing-the-dumping-the-dollar-conspiracy/.

10 Was the Iraqi Shift to Euro Currency to "Real” Reason for War? AMI. Retrieved from http://www.monetary.org/was-the-iraqishift-to-euro-currency-to-real-reason-for; EU Could Switch to Euros in Oil Trade With Iran, OilPrice.com. https://oilprice.com.

${ }^{11}$ Iran switches from dollar to euro for official reporting currency, Reuters. Retrieved from https://www.reuters.com/.../us-irancurrency-euro/Iran-switches-from-dollar-to-euro-f; Currency War Escalation: Iran Wants Euros Instead of US Dollars for. Retrieved from https://www.globalresearch.ca/currency-war...iran...euros-instead...us-dollars...oil.../5506.
} 
Iran in national currencies and the riyal on July 4, 2018, after the opening of the first bank credit in this framework).

Iran and Turkey will try to use measures to boost their economy, including the following:

Reduce the demand for dollar or euro through the imposition of measures, including import in other currencies (rubles, euros, etc.).

(1) Establishing a banking system for local currencies in foreign trade;

(2) Reliance on the support of regional and international partners of Turkey and Iran;

(3) Use monetary policy tools;

(4) Iran and Turkey are serious, not hypothetical, to dilute its expansionist economic policies.

The collapse of the Iranian rial and Turkish lira may have been caused by US sanctions and taxes on Iranian products. But the real reason for the economic turmoil in Turkey is also due to increased growth, a growing trade deficit and many coffers exceeding $\$ 220$ billion with accrued interest due to default.

Building a regional banking system by linking the Iranian riyal to the Turkish lira, the Iraqi dinar, the Russian ruble, and the Chinese yen counter the prohibition of the sale of foreign currencies.

Gold versus gas and oil in dealing with countries learned from Iranian oil and gas.

At the same time, work on tightening monetary policy control inflation rates.

The Iranian government to develop a fiscal policy based on the sale of dollars at artificially low rates on the basis of the theory that this keeps prices low.

The issue is very serious after 2/11/2018 when America prevents Iran from selling its oil will happen the following:

As exports drop and exchange rates fall artificially, the government will face one of the two worst-case scenarios:

The first is lower revenues; and the second is high costs.

This may impose a budget cut and this could have serious political consequences.

How this affects the internal stability of Iran? The simple equation lies in the following fact:

That high prices, high unemployment, budget cuts, and rampant corruption are all a recipe for public anger at the Iranian government.

Is this what Israel and the United States of America want to impose financial and economic sanctions on the demonstrations and popular anger against the Iranian government?

More precisely in short economic terms, the more severe Iran's economic problems are, the more worried the general public is about the continued collapse of the Iranian riyal.

And the anti-American media coverage that the war is coming against Iran and the issue is a matter of time.

The more fears of war prevents foreign and Iranian investors from launching new project and makes consumers seek to find a safe haven for their stocks by converting them into dollars for example which affects the withdrawal of the hard currency dollar from the market and increased inflation and the collapse of the Iranian riyal.

A legitimate question remains: Will the Iranian government borrow and who will approve the granting of emergency loans?

Because in practice if inflation and the fall of the riyal continue, especially with the insistence of the United States of America to implement the ban on the export of Iranian oil on 2/11/2018, Iran has no choice but to borrow. 
The Islamic Republic of Iran faced the next severe economic challenge in the mid-1990s.

After borrowing $\$ 14$ billion during the sudden post-war boom from 1991 to 1994, Iranian bills had to be paid as the administration of US President Bill Clinton increased pressure on its allies not to grant loans to Iran, and then the administration imposed comprehensive US sanctions on Iran in 1995.

Iran could have solved this problem by reducing its support for Islamic resistance movements, but it has continued to support the Islamic Resistance and will not relinquish its project by supporting the axis of resistance against America and Israel.

Instead, Iran spent billions of dollars over the next three years to repay loans of $\$ 8$ billion and relied on Europe and Japan to reschedule loans of up to $\$ 16$ billion.

Austerity measures have reduced imports from \$23 billion in fiscal 1992-1993 to \$13 billion in 1994-1995 fiscal years and remained at that level for the next fiscal year.

In short, Iran preferred to reduce its imports to about half, instead of changing its foreign policy based on supporting the Islamic Resistance Movement in Lebanon, Palestine, and all parts of the world.

But the Iranian government should take into account that the year 2018 is different from the nineties, especially as the conditions of the United States of America are summarized as follows:

Unilateral withdrawal by the United States re-imposes the re-imposition of US sanctions on Iran, in light of the European concern opposed to the US withdrawal.

And that US Secretary of State Mike Pompeo has recently announced a list of 12 demands as a condition for the conclusion of a new nuclear agreement with Iran.

US sanctions have imposed many restrictions on trade in gold and many minerals, along with restrictions on aviation and the automobile industry. Sanctions will also include measures for Iran's financial and oil institutions, which would punish individuals on the US Treasury sanctions list before the nuclear deal.

And that the United States will seek to compel Iran to comply with pressure; the demands represent a declaration of economic war on Iran, and even declare a media war against it (The terms of Pompeo also included the withdrawal of all its forces from Syria and stop supporting Houthis in Yemen).

In addition to giving the IAEA full details of its former nuclear weapons program, it abandoned such work forever and ended its "threatening behavior" towards its neighbors, in the words of the US Secretary of State, including its threats to destroy Israel and launch rockets into Saudi Arabia and the United Arab Emirates, the release of all US citizens and citizens of US partners.

\section{References}

Al-Atrisi, T. (2006). Republic of the difficult Iran in its internal transformations and regional policy. Lebanon: Dar Al-Satti.

Al-Rawai, R. (2003). Iran's nuclear program and its impact on the Middle East. Damascus: Dar Al-Awael. Arafa, K. (2014). Energy security and strategic effects. Naif: Arab University for Security Sciences.

Baylawi, H. (2001). Contemporary international economic system. Kuwait: The World of Knowledge Series. Duran, R. (2011). The reasons for the rise of the Turkish model. Dubai: Center for Studies and Research.

Hassan, S. Y. (2006). International economic relations. Baghdad: Dar Al-Rowad.

Hazem, S. (2003). Oil dimensions in the US war on Iraq. Damascus: Dar Al-Fikr.

Howard, R. (2007). Oil of Iran and his role in defying the influence of the United States. Lebanon: Arab Science House.

Mahmoud, M. (2003). European participation and regional cooperation. Cairo: Book of Al-Ahram Economic.

Maraashli, M. (1987). The reality of contemporary international economic policy. Beirut: University Institution for Studies.

Mohammed, R. (2007). Tajin partnership contracts. Cairo: Dar Al-Nahdah Al-Arabiya. 
Momen, M. E. A. (2012). Third republic in Iran. Cairo: Egyptian Book Authority.

Omar, H. (1998). Contemporary economic integration theory and practice. Cairo: Arab Thought House.

Timerman, K. R. (2006). Countdown to the nuclear standoff confrontation with Iran's. Millionaires House. 